\title{
Elimination of Serum Free and Total Prostate-Specific Antigen after Radical Retropubic Prostatectomy ${ }^{1}$ )
}

\author{
Michael Lein ${ }^{1,3}$, Brigitte Brux ${ }^{2}$, Klaus Jung ${ }^{1}$, Wolfgang Henke ${ }^{1}$, Frank Koenig' ${ }^{1.3}$, Carsten Stephan ${ }^{1}$, \\ Dietmar Schnorr ${ }^{1}$ and Stefan A. Loening ${ }^{1}$ \\ ${ }^{1}$ Klinik für Urologie, Universitätsklinikum Charité, Humboldt Univeristät zu Berlin, Berlin, Germany \\ ${ }^{2}$ Institut für Pathologische und Klinische Biochemie, Universitätsklinikum Charité, \\ Humboldt Universität zu Berlin, Berlin, Germany \\ ${ }^{3}$ Wellman Laboratories, Massachusetts General Hospital, Harvard Medical School, Boston, USA
}

Summary: Elimination kinetics of serum total and free prostate-specific antigen were studied for a ten days course after radical retropubic prostatectomy on 11 patients suffering from organ confined prostate cancer. Samples were taken before operation, immediately after finishing the operation and 1, 2, 3, 4, 5, $6 \mathrm{~h}$ after prostatectomy and then once a day for the following ten days. The measurements were performed with AxSym assays from Abbott Laboratories. The elimination of both total and free prostate-specific antigen followed a biphasic kinetics. In the fast phase, the average of the individual elimination half-lives of total and free prostate-specific antigen amounted to $6.3 \mathrm{~h}$ $(\mathrm{SD}=6.1 \mathrm{~h}$; range: 0.55 to $37.1 \mathrm{~h})$ and $0.57 \mathrm{~h}(\mathrm{SD}=0.18 \mathrm{~h}$; range: 0.22 to $0.89 \mathrm{~h})$, respectively. In the slow phase, total prostate-specific antigen disappeared with an average half-life of $85.6 \mathrm{~h}(\mathrm{SD}=11 \mathrm{~h}$; range: 47.2 to $261.7 \mathrm{~h})$ and free prostate-specific antigen with an average half-life of $14.4 \mathrm{~h}(\mathrm{SD}=10.4 \mathrm{~h}$; range: 2.4 to $30.3 \mathrm{~h})$. These results might be significant for the use of free and total prostate-specific antigen and its ratio as a diagnostic and prognostic tool.

\section{Introduction}

Prostate-specific antigen is the most powerful serum marker for the diagnosis of prostate cancer $(1,2)$. It is used for screening, assessment of treatment response and prediction of relapse. However, increased prostatespecific antigen concentrations occur not only in patients with adenocarcinoma of the prostate but also in case of benign prostatic hyperplasia, inflammation and after manipulation (1).

Recently, it has been found that prostate-specific antigen exists in different molecular forms (3-6). Most of the prostate-specific antigen is complexed to the protease inhibitors $\alpha_{1}$-antichymotrypsin, $\alpha_{2}$-macroglobulin and $\alpha_{1}$-antitrypsin. About $10-20 \%$ of the total prostate-specific antigen circulates as a free form in blood. Patients with prostate cancer have a lower proportion of this free form than patients with benign prostatic hyperplasia $(3-6)$. It has been suggested that the ratio of the free to total prostate-specific antigen allows a better differentiation between patients suffering from prostate cancer and those with benign prostatic hyperplasia (7-9). The reason for this phenomenon is not clear since little is known about the metabolism of the various molecular

\footnotetext{
1) The work was supported by a grant from the Family-Klee-Foundation. We thank Abbott Laboratories for supplying test kits free of charge. The study includes parts of the doctoral thesis of Carsten Stephan.
}

forms of prostate-specific antigen. It has been suggested that an increased synthesis of $\alpha_{1}$-antichymotrypsin occurs in tumour cells. Thus, more free prostate-specific antigen is complexed in tumour cells than in normal cells and leads to these changes observed in serum (10). Other authors believe that the changed glycation rate of prostate-specific antigen found in dysplastic cells results in characteristic differences of the elimination of prostate-specific antigen from blood (11).

Whereas the clearance rates of total prostate-specific antigen were intensively studied, scarce data exist on the elimination kinetics of the different molecular forms mentioned above $(12-17)$. To get further insight into this problem, it seems necessary to compare the elimination kinetics of free and total prostate-specific antigen. Thus, this study was designed to determine the elimination kinetics of free and total prostate-specific antigen following radical prostatectomy in patients with organ confined prostate cancer.

\section{Materials and Methods}

Study material and blood sampling

The study approved by the ethical standards committee of the hospital was performed on 11 men ( 55 to 71 years) undergoing radical retropubic prostatectomy. The diagnosis of prostate cancer was established histopathologically. The patients had no metastases (pT2, T3, pN0, M0). During the study no patients received blood or plasma infusions. 
Intravenous blood samples were taken according to the following scheme: before operation; immediately after finishing the operation (generally within the first $30 \mathrm{~min}$ ); 1, 2, 3, 4, 5, $6 \mathrm{~h}$ after prostatectomy and then once a day for the following ten days. Blood samples were centrifuged at $1500 \mathrm{~g}$ for $10 \mathrm{~min}$ after allowing the blood to clot for $1 \mathrm{~h}$ at room temperature. The serum was frozen at $-80^{\circ} \mathrm{C}$ within 2 hours after collection and was not thawed before test performance.

Assays

AxSym test kits (Abbott Diagnostics, Abbott Park, IL, USA) were used for measuring free and total prostate-specific antigen. These assays are microparticle enzyme immunoassays. The sample is incubated with microparticles coated with antibodies that bind a specific epitope either of total or free prostate-specific antigen. An aliquot of the reaction mixture is automatically pipetted into a special reaction cell where the microparticles bind irreversibly to a glass fibre matrix. Unbound materials are removed by washing and anti-prostate-specific antigen antibody labelled with alkaline phosphatase is added that binds to the antibody-antigen complex. The unbound components are removed, the substrate 4-methylumbelliferyl phosphate is added and the fluorescent 4-methylumbelliferone which is released is measured on the immunoassay analyser AxSym.

Total and free prostate-specific antigen concentrations were simultaneously measured as a single run for each patient. Ten separate runs were performed for the samples of the 11 patients. Each run was checked by two control sera for total prostate-specific antigen (4.01 and $15.4 \mu \mathrm{g} / \mathrm{l})$ and three control sera for free prostate-specific antigen $(0.39 ; 0.96 ; 6.85 \mu \mathrm{g} / 1)$. The between-run precisions calculated from these ten runs were between 2.6 and $4.7 \%$. The withinrun precisions $(\mathrm{n}=12)$ were between 2.1 and $3.5 \%$. The lower detection limits were calculated on the basis of the means and $3 \mathrm{SD}$ of 10 replicate intra-assay determinations of the zero calibrators of the total and free prostate-specific antigen assays. The lower detection limits were $0.096 \mu \mathrm{g} / 1$ for total and $0.005 \mu \mathrm{g} / 1$ for free prostatespecific antigen.

\section{Calculations}

The evaluation of the elimination kinetics of free and total prostatespecific antigen was performed by using the equation

prostate-specific antigen $n_{t}=a^{-k_{1} \cdot t}+b^{-k_{2} \cdot t}$

The data of free and total prostate-specific antigen clearance were fitted by applying a non-linear regression procedure (18). Statistical calculations were performed by the statistical package Statgraphics, version 5.01 (Statistical Graphics, Rockville, USA). The t-test according to Student with paired data was used.

\section{Results and Discussion}

Serum concentrations of total and free prostate-specific antigen were measured before and after radical retropubic prostatectomy in 11 patients. The percentage ratios of free to total prostate-specific antigen before prostatectomy were $<15 \%$ in all patients except one patient with $18 \%$ (tab. 1). These results confirmed our previous data that the ratio of free to total prostate-specific antigen was lower in patients with prostate cancer than in healthy men or patients with benign prostatic hyperplasia (7). The concentrations found before prostatectomy, 30 min after operation as the first point after the prostate was removed and then 10 days afterwards demonstrated that the concentrations varied in a broad range (tab, 1). By surgical intervention, concentrations of free, but not of total prostate-specific antigen, were increased compared to the data obtained before prostatectomy. Both forms decreased rapidly afterwards. However, the ratio of free to total prostate-specific antigen at day $10 \mathrm{after}$ prostatectomy compared to the initial value showed that the free form was more rapidly eliminated. Consequently, the percentage ratio of free to total prostatespecific antigen decreased about 10 -fold, from $10.4 \%$ to $0.93 \%$. At the end of this ten day follow-up study, the concentrations of both total and free prostate-specific antigen were still higher than the detection limits of the assays for total and free prostate-specific antigen (0.096 and $0.005 \mu \mathrm{g} / \mathrm{l}$, respectively). Thus, all data concentrations measured could be used for the calculation of elimination kinetics.

The calculations of clearance rates of prostate-specific antigen were performed with normalized data. For the purpose of normalizing the varying concentrations of prostate-specific antigen, the concentration of prostatespecific antigen of each patient measured in the serum sample collected within 30 min after finishing the operation was set at 1.0. All other concentrations of prostatespecific antigen of the respective patient were calculated as fractiles of that initial value. The clearance of both total and free prostate-specific antigen was characterized by biexponential kinetics (fig. 1). A fast phase of elimination was found during the first $8 \mathrm{~h}$ after prostatectomy followed by a slow phase. In the fast phase, the means of the 11 individual elimination half-lives of total and free prostate-specific antigen amounted to $6.3 \mathrm{~h}$ (SD $=6.1 \mathrm{~h}$; range: 0.55 to $37.1 \mathrm{~h}$ ) and to $0.57 \mathrm{~h}$ (SD $=0.18 \mathrm{~h}$; range: 0.22 to $0.89 \mathrm{~h}$ ), respectively. In the slow phase, total prostate-specific antigen disappeared with an average half-life of $85.6 \mathrm{~h}$ (SD $=11 \mathrm{~h}$; range: 47.2 to $261.7 \mathrm{~h}$ ) and free prostate-specific antigen with an average half-life of $14.4 \mathrm{~h}(\mathrm{SD}=10.4 \mathrm{~h}$; range: 2.4 to $30.3 \mathrm{~h}$ ).

There are several studies in the literature regarding the disappearance rate of total prostate-specific antigen after radical prostatectomy $(12-17)$. Both monophasic and biphasic patterns have been described. Oesterling et al. (14) and Semjonow et al. $(15,19,20)$ both described a monoexponential elimination kinetics of total prostatespecific antigen and determined a half-life of $75.6 \mathrm{~h}$ and 38.4 h, respectively. Stamey et al. (13) and Van Straalen et al. (17) described a two phase elimination with a shorter half-life of $12.6 \mathrm{~h}$ and $1.63 \mathrm{~h}$, respectively and a longer half-life of $52.8 \mathrm{~h}$ and $111 \mathrm{~h}$, respectively. Our half-life data amounting to $6.3 \mathrm{~h}$ and $85.6 \mathrm{~h}$ were in this range. It was assumed that the delay of the first serum collection after surgery, for example $48 \mathrm{~h}$ as done by Oesterling et al. (14) resulted in missing the fast phase of elimination (21). Thus, the study design and especially the sampling apparently affect the form of the elimination kinetics (22). Our study design considered 
Tab. 1 Concentrations of free and total prostate-specific antigen and their ratio before and after radical prostatectomy. ${ }^{\mathrm{a}}$

\begin{tabular}{llll}
\hline Time & $\begin{array}{l}\text { Total } \\
\text { prostate-specific antigen } \\
(\mu \mathrm{g} / \mathrm{l})\end{array}$ & $\begin{array}{l}\text { Free } \\
\text { prostate-specific antigen } \\
(\mu \mathrm{g} / \mathrm{l})\end{array}$ & $\begin{array}{l}\text { Ratio of free to total } \\
\text { prostate-specific antigen } \\
(\%)\end{array}$ \\
\hline Before operation & $13.5 \pm 10.9$ & $1.14 \pm 0.86$ & $10.4 \pm 3.9$ \\
30 min after operation & $13.8 \pm 8.68$ & $2.87 \pm 2.37^{*}$ & $20.9 \pm 9.7^{* * *}$ \\
10 d after operation & $0.85 \pm 0.68^{* *}$ & $0.01 \pm 0.01^{* * *}$ & $0.93 \pm 0.45^{* * *}$ \\
\hline
\end{tabular}

${ }^{\text {a }}$ Data are arithmetic mean values \pm 1 SD of 11 patients. $*=p<0.05 ; \quad * *=p<0.01 ; \quad * * *=p<0.001$ versus values before operation (t-test with paired data).

that suggestion by measuring samples obtained in shortterm intervals after prostatectomy. Thus, the two phases of elimination both for total and free prostate-specific antigen observed in our study stronlgy support the assumption that sampling is important for a correct evaluation of elimination kinetics.
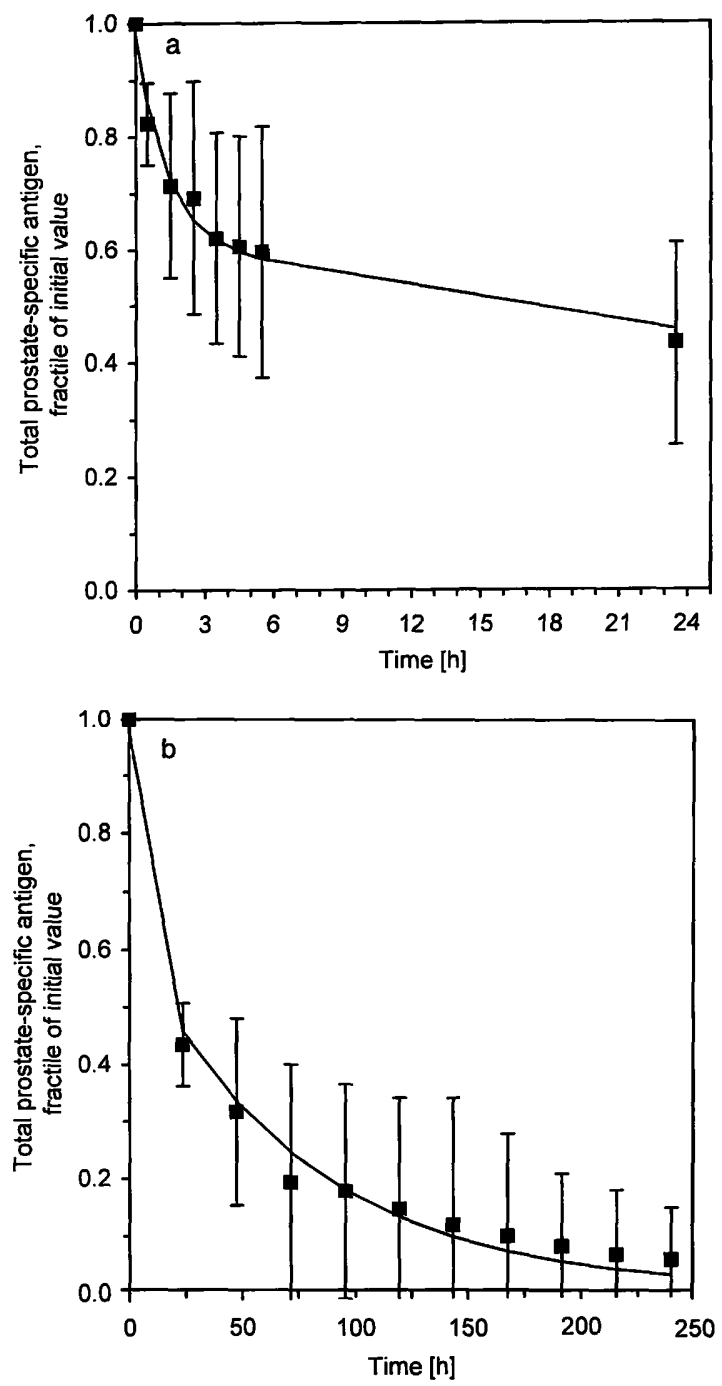

Fig. 1 Elimination of serum total prostate-specific antigen from blood following radical retropubic prostatectomy. The curves represent mean values $\pm 1 \mathrm{SD}$ from 11 patients expressed as fractiles of the initial concentration measured within $30 \mathrm{~min}$ after finishing the operation. The values obtained during the first $24 \mathrm{~h}$ after prostatectomy are presented in (a) and the values between the first and $10^{\text {th }}$ day after prostatectomy in (b).
Studies on eliminiation kinetics have suggested that the half-life determination is a more powerful predictive tool for a relapse than the evidence of "undetectable" concentrations of prostate-specific antigen (19). For example, relapse-free patients had a shorter half-life of the elimination of prostate-specific antigen than patients with recurrent disease during a follow-up of two years after prostatectomy. It might be that the determination of the half-life of free prostate-specific antigen has a better clinical validity than the determination of the corresponding half-life of total prostate-specific antigen (22).

It has been suggested that the biphasic elimination pattern is caused by the occurrence and biochemical characteristics of the molecular forms of prostate-specific antigen (23). The occurrence of various forms of prostate-specific antigen was briefly outlined in the introduction. About $80 \%$ of serum prostate-specific antigen is complexed to the protease inhibitors $\alpha_{1}$-antichymotrypsin, $\alpha_{1}$-antitrypsin and $\alpha_{2}$-macroglobulin. The rest of serum prostate-specific antigen occurs as free, non-complexed form. The complex of $\alpha_{1}$-antichymotrypsin with prostate-specific antigen is the major form of these complexes, whereas the prostate-specific antigen bound to the other two inhibitors is only found in small concentrations $(5,24)$. However, little is known about the metabolism of prostate-specific antigen and its forms. As reliable methods for determining the complexes of prostate-specific antigen have not yet been available, the conclusions about the metabolism must rely upon measurements of total and free prostate-specific antigen. Our data show that free prostate-specific antigen is similarly eliminated as total prostate-specific antigen by a biphasic kinetics. However, the half-lives of the fast and the slow phases are clearly lower than those of the total prostate-specific antigen. After our investigations were finished, the results of two studies on the elimination kinetics of free prostate-specific antigen became available $(22,23)$. The authors also described a biphasic elimination pattern and calculated half-lives for the fast phase of $1.2 \mathrm{~h}$ and $1.9 \mathrm{~h}$, respectively and for the slow phase of $22 \mathrm{~h}$ and $6 \mathrm{~h}$, respectively. These results are in general agreement with our mean half-lives of $0.57 \mathrm{~h}$ and $14.4 \mathrm{~h}$. 

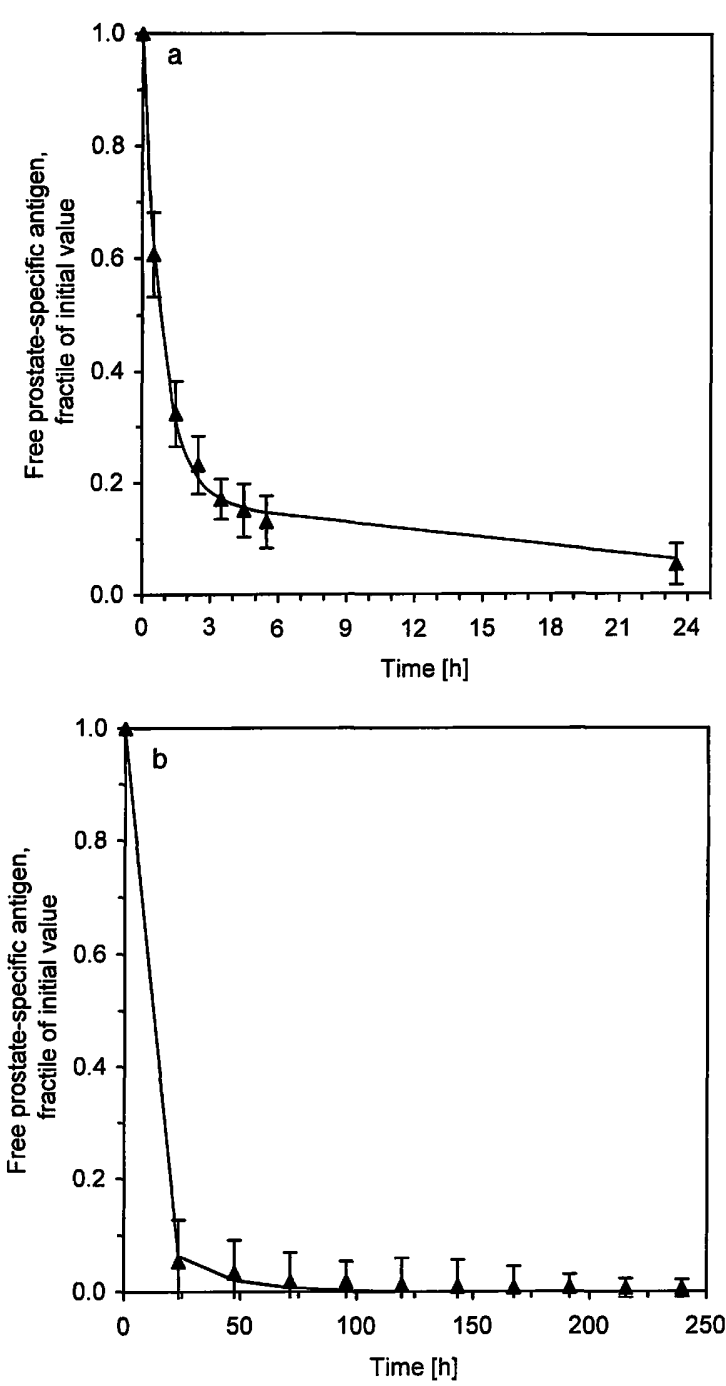

Fig. 2 Elimination of serum free prostate-specific antigen from blood following radical retropubic prostatectomy. The curves represent mean values $\pm 1 \mathrm{SD}$ from 11 patients expressed as fractiles of the initial concentration measured within $30 \mathrm{~min}$ after finishing the operation. The values obtained during the first $24 \mathrm{~h}$ after prostatectomy are presented in (a) and the values between the first and $10^{\text {th }}$ day after prostatectomy in (b).

The dramatic decrease of the free prostate-specific antigen in the early phase of elimination might be the result of its rapid binding to $\alpha_{2}$-macroglobulin and/or $\alpha_{1}$-antichymotrypsin $(4,25)$. The complexation with $\alpha_{2}$-macroglobulin cannot be ascertained by common immunoassays for prostate-specific antigen since $\alpha_{2}$-macroglobulin encapsulates all epitopes of prostate-specific antigen (25). The in vitro rate of complex formation of prostate-specific antigen with $\alpha_{2}$-macroglobulin was more pronounced than that with $\alpha_{1}$-antichymotrypsin (4). In addition, there are special "nicked" forms of prostate-specific antigen containing multiple proteolytic cleavages that lose the binding affinity to $\alpha_{1}$-antichymotrypsin (25). That could explain the occurrence of free prostate-specific antigen in serum despite a $10^{4}$ to $10^{5}$ fold excess of $\alpha_{1}$-antichymotrypsin in the blood compared to prostate-specific antigen (24). Thus, other pro- cesses of elimination of the free form of prostate-specific antigen have to be considered. The slower phase of the biphasic elimination of free prostate-specific antigen could result. Free prostate-specific antigen with a relative molecular mass of about 28000 corresponds to the low molecular mass proteins that are generally catabolized and eliminated by the kidney (26). Agha et al. (27) tried to identify the main site where prostate-specific antigen is metabolized. This evaluation was based on selective arterial and venous sampling and the analysis of concentration changes across the renal, hepatic, pulmonary and pelvic circulation. The kidneys and lungs had no significant role in the elimination of prostatespecific antigen. The non-significant role of the kidney in the clearance rate of prostate-specific antigen was supported by unchanged serum concentrations of prostate-specific antigen found in men with chronic renal failure (28). The prostate-specific antigen complexed with $\alpha_{1}$-antichymotrypsin or $\alpha_{2}$-macroglobulin is far too large to be filtered through the glomerular membrane. The liver was the most likely site of prostate-specific antigen metabolism (27). Lilja et al. (4) also speculated that the liver could be the main site of prostate-specific antigen metabolism. That could be taken into consideration both for free and complexed prostate-specific antigen. Different glycoated variants of prostate-specific antigen were found by the chromatofocusing technique (11). The heterogeneity of prostate-specific antigen could influence the liver uptake of these forms due to the involvement of the asialo-glycoprotein receptor in this process. Similar effects were described for the elimination of circulating $\gamma$-glutamyltransferase (29). In addition to the effect of this general receptor, the involvement of special receptors on liver cells, which can eliminate the complex between the serine protease and its inhibitors $(30,31)$, could be significant. It was suggested that these receptors might be responsible for the hepatic uptake of the complex of prostate-specific antigen with $\alpha_{1}$-antichymotrypsin (27).

In conclusion, our results have both biochemical and clinical significance. First, the findings that both free and complexed forms of prostate-specific antigen are eliminated by a biphasic kinetics with different halflives improve our understanding of the metabolism of prostate-specific antigen. However, the exact mechanisms have to be elucidated. Secondly, the longer halflife of total prostate-specific antigen compared with the free form indicates that after prostatic manipulation (e. g., digital rectal examination, biopsy etc.) about three weeks (17) have to pass in order to reach the baseline level of the free and total prostate-specific antigen. Only then might the ratio of free to total prostate-specific antigen be useful as a discriminator between patients with prostate cancer and benign prostatic hyperplasia. 


\section{Acknowledgements}

The work was supported by a grant from the Family-Klee-Foundation. We thank Abbott Laboratories for providing test kits free of charge.

\section{References}

1. Armbruster DA. Prostate-specific antigen: biochemistry, analytical methods, and clinical application [review]. Clin Chem 1993; 39:181-95.

2. Oesterling JE. Prostate specific antigen: a critical assessment of the most useful tumor marker for adenocarcinoma of the prostate. J Urol 1991; 145:907-23.

3. Wood WG, van der Sloot E, Bohle A. The establishment and evaluation of luminescent-labelled immunometric assays for prostate-specific antigen- $\alpha_{1}$-antichymotrypsin complexes in serum. Eur J Clin Chem Clin Biochem 1991; 29:787-94.

4. Lilja H, Christensson A, Dahlen U, Matikainen MT, Nilsson O, Pettersson K, et al. Prostate-specific antigen in serum occurs predominantly in complex with $\alpha_{1}$-antichymotrypsin. Clin Chem 1991; 37:1618-25.

5. Stenman UH, Leinonen J, Alfthan H, Rannikko S, Tuhkanen $\mathrm{K}$, Alfthan $\mathrm{O}$. A complex between prostate-specific antigen and $\alpha_{1}$-antichymotrypsin is the major form of prostate-specific antigen in serum of patients with prostatic cancer: assay of the complex improves clinical sensitivity for cancer. Cancer Res 1991; 51:222-6.

6. Stamey TA, Chen Z, Prestigiacomo A. Serum prostate specific antigen binding alpha 1-antichymotrypsin: influence of cancer volume, location and therapeutic selection of resistant clones. J Urol 1994; 152:1510-4.

7. Jung K, Stephan C, Lein M, Henke W, Schnorr D, Brux B, et al. Analytical performance and clinical validity of two free prostate-specific antigen assays compared. Clin Chem 1996; 42:1026-33

8. Oesterling JE, Jacobsen SJ, Klee GG, Pettersson K, Piironen $\mathrm{T}$, Abrahamsson PA, et al. Free, complexed and total serum prostate specific antigen: the establishment of appropriate reference ranges for their concentrations and ratios. J Urol $1995 ; 154: 1090-5$.

9. Catalona WJ, Smith DS, Wolfert RL, Wang TJ, Rittenhouse HG, Ratliff TL, et al. Evaluation of percentage of free serum prostate-specific antigen to improve specificity of prostate cancer screening. J Am Med Assoc 1995; 274:1214-20.

10. Björk T, Hulkko S, Bjartell A, di Sant'Agnese A, Abrahamsson $\mathrm{PA}$, Lilja $\mathrm{H}$. Alpha l-antichymotrypsin production in PSA-producing cells is common in prostate cancer but rare in benign prostatic hyperplasia. Urology 1994; 43:427-34.

11. Huber PR, Schmid HP, Mattarelli G, Strittmatter B, Vansteenbrugge GJ, Maurer A. Serum free prostate specific antigen: isoenzymes in benign hyperplasia and cancer of the prostate. Prostate 1995; 27:212-9.

12. Haab F, Meulemans A, Boccongibod L, Dauge MC, Delmas V. Clearance of serum PSA after open surgery for benign prostatic hypertrophy, radical cystectomy, and radical prostatectomy. Prostate $1995 ; 26: 334-8$.

13. Stamey TA, Yang N, Hay AR, McNeal JE, Freiha FS, Redwine E. Prostate-specific antigen as a serum marker for adenocarcinoma of the prostate. N Engl J Med 1987; 317:909-17.

14. Oesterling JE, Chan DW, Epstein JI, Kimball AW Jr, Brzek DJ, Rock RC, et al. Prostate specific antigen in the preoperative and postoperative evaluation of localized prostatic cancer treated with radical prostatectomy. J Urol 1988; 139:766-72.

15. Semjonow A, Hamm M, Rathert P. Elimination kinetics of prostate-specific antigen serum and urine. Int J Biol Markers 1994; 9:15-20.

16. Brändle E, Gottfried HW, Maier S, Flohr P, Steinbach G, Hautmann RE. Ist die radikale Prostatektomie ein geeignetes Modell zur Bestimmung der PSA-Halbwertszeit? Urologe A $1995 ; 34: 419-23$.
17. van Straalen JP, Bossens MM, de Reijke TM, Sanders GT. Biological half-life of prostate-specific antigen after radical prostatectomy. Eur J Clin Chem Clin Biochem 1994; 32:53-5.

18. Holzhütter HG, Colosimo A. SIMFIT: a microcomputer software-toolkit for modelistic studies in biochemistry. Comput Appl Biosci 1990; 6:23-8.

19. Semjonow A, Hamm M, Rathert P. Prediction of tumor recurrence after radical prostatectomy using elimination kinetics of prostate-specific antigen. World J Urol 1993; 11:218-20.

20. Semjonow A, Hamm M, Rathert P. Half-life of prostate-specific antigen after radical prostatectomy: the decisive predictor of curative treatment? Eur Urol 1992; 21:200-5.

21. Pontes JE, Jabalameli P, Montie J, Foemmel R, Howard PD, Boyett J. Prognostic implications of disappearance rate of biologic markers following radical prostatectomy. Urology 1990; 36:415-9.

22. Partin AW, Piantadosi S, Subong ENP, Kelly CA, Hortopan S, Chan DW, et al. Clearance rate of serum-free and total PSA following radical retropubic prostatectomy. Prostate 1996; 7 (Suppl):35-9.

23. Richardson TG, Wojno KJ, Liang LW, Giacherio DA, England BG, Henricks WH, et al. Half-life determination of serum free prostate-specific antigen following radical retropubic prostatectomy. Urology 1996; 48:40-4.

24. Christensson A, Björk T, Nilsson O, Dahlen U, Matikainen MT, Cockett ATK, et al. Serum prostate specific antigen complexed to $\alpha_{1}$-antichymotrypsin as an indicator of prostate cancer. J Urol 1993; 150:100-5.

25. Leinonen J, Zhang WM, Stenman UH. Complex formation between PSA isoenzymes and protease inhibitors. J Urol 1996; 155:1099-103.

26. Maack T, Johnson V, Kau ST, Figueiredo J, Sigulem D. Renal filtration, transport, and metabolism of low-molecular-weight proteins: a review. Kidney Int 1979; 16:251-70.

27. Agha AH, Schechter E, Roy JB, Culkin DJ. Prostate specific antigens is metabolized in the liver. J Urol 1996; 155:1332-5.

28. Kabalin JN, Hornberger JC. Prostate-specific antigen is not excreted by human kidney or eliminated by routine hemodialysis. Urology $1991 ; 37: 308-10$.

29. Huseby NE, Mortensen B, Smedsrod B. Clearance of circulating gamma-glutamyltransferase by the hepatic galactose receptor. Variability in clearance rate due to carbohydrate heterogeneity of the enzyme. Biochim Biophys Acta 1993; 1156:283-7.

30. Perlmutter DH, Glover GI, Rivetna M, Schasteen CS, Fallon RJ. Identification of a serpin-enzyme complex receptor on human hepatoma cells and human monocytes. Proc Natl Acad Sci USA 1990; 87:3753-7.

31. Mast AE, Enghild JJ, Pizzo SV, Salvesen G. Analysis of the plasma elimination kinetics and conformational stabilities of native, proteinase-complexed, and reactive site cleaved serpins: comparison of alpha 1-proteinase inhibitor, alpha 1-antichymotrypsin, antithrombin III, alpha 2-antiplasmin, angiotensinogen, and ovalbumin. Biochemistry 1991; 30:1723-30.

\section{Received March 3/May 26, 1997}

Corresponding author: Prof. Dr. Klaus Jung, Forschungsabteilung der Klinik für Urologie, Universitätsklinikum Charité, HumboldtUniversität zu Berlin, Schumannstraße 20/21, D-10098 Berlin, Germany 
